\title{
DIAKRONIKA
}

\author{
Vol. 18 No. 1 Th. 2018 p: 54-64 \\ ISSN: 1411-1764 (Print) | 2620-9446 (Online) \\ http://diakronika.ppj.unp.ac.id
}

\section{Analisis Kebutuhan Pengembangan Media Pembelajaran Video Candi Muara Jambi Berbasis Sejarah Lokal Pada Mata Kuliah Sejarah Indonesia}

\author{
Nur Agustiningsih, Satriyo Pamungkas
}

\begin{abstract}
The development of technology and communication has a big influence on all fields of life including in the field of education. Creativity and innovation is needed in developing learning media including in learning history. The purpose of this research is to obtain: 1) description of the use of learning media in the learning process in the field, 2) obstacles faced by lecturer in Indonesian history up to the 15th century learning 3) media formulations needed in learning Indonesian History. This research is a qualitative descriptive research. Data collection techniques used are interviews, observation and analysis of documents. The informan were selected through purposive sampling. Data validation used triangulation. Data analysis techniques used interactive analysis models including data collection, data reduction, data presentation and conclusion drawing. The result of the research shows that 1) Lecturer has used learning media as a learning resource in the learning process, but are still less varied. The media used is still limited to the use of powerpoint which displays images and text only. 2) The constraints faced by the lecturer in delivering the material about the muara jambi temple are limited references and learning resources. 3) Media that needs to be developed in learning is video.
\end{abstract}

Keywords: need analysis, learning media, local history, video, Muara Jambi tempel

\footnotetext{
Abstrak

Perkembangan teknologi dan komunikasi yang pesat memberikan pegaruh terhadap segala bidang kehidupan termasuk dalam bidang pendidikan. Diperlukan kreativitas dan inovasi baru dalam mengembangkan media pembelajaran termasuk dalam pembelajaran sejarah. Tujuan penelitian ini adalah untuk memperoleh: 1) deskripsi penggunaan media pembelajaran dalam proses pembelajaran di lapangan, 2) kendala yang dihadapi dosen mata kuliah Sejarah Indonesia hingga abad $15 \mathrm{M}$ dalam pembelajaran, 3) formulasi media pembelajaran yang dibutuhkan dalam pembelajaran Sejarah Indonesia. Penelitian tergolong jenis penelitian deskriptif kualitatif. Teknik pengambilan data yang digunakan adalah wawancara, observasi dan analisis dokumen. Pemilihan informan dilakukan dengan cara purposive sampling. Validasi data dilakukan dengan triangulasi. Teknik analisis data menggunakan model analisis interaktif mencakup pengumpulan data, reduksi data, sajian data dan penarikan kesimpulan. Hasil penelitian menunjukkan bahwa 1) Dosen telah menggunakan media pembelajaran sebagai sumber belajar dalam proses pembelajaran, namun masih kurang bervariasi. Media yang digunakan masih terbatas
} 
Nur Agustiningsih, Satriyo Pamungkas

Analisis Kebutuhan Pengembangan Media Pembelajaran Video Candi Muara Jambi Berbasis Sejarah Lokal Pada Mata Kuliah Sejarah Indonesia

pada penggunaan powerpoint yang di dalamnya menampilkan gambar dan teks saja. 2) Kendala yang dihadapai dosen dalam penyampaian materi tetang candi Muara Jambi adalah keterbatasan referensi dan sumber belajar. 3) Media yang perlu dikembangakan dalam pembelajaran adalah video.

Kata Kunci: analisis kebutuhan, media pembelajaran, sejarah lokal, video, candi Muara Jambi

This work is licensed under the Creative Commons Attribution-Share Alike 4.0 International License.

\section{Pendahuluan}

Proses pembelajaran merupakan salah satu unsur penting untuk mencapai tujuan pembelajaran. Pembelajaran adalah proses kerjasama antara guru dan siswa dalam memanfaatkan segala potensi dan sumber yang ada baik potensi yang bersumber dari dalam diri siswa itu sendiri seperti minat, bakat dan kemampuan dasar yang dimiliki, termasuk gaya belajar. Potensi yang ada diluar diri siswa antara lain; lingkungan, sarana dan sumber belajar sehingga upaya untuk mencapai tujuan belajar tertentu. Dalam UU RI No. 20 Tahun 2003 tentang Sisdiknas juga disebut bahwa pembelajaran adalah proses interaksi peserta didik dengan pendidik dan sumber belajar pada suatu lingkungan (Sanjaya, 2008). Lebih lanjut (Trianto, 2007) mendefinisikan pembelajaran sebagai usaha sadar dari seorang guru untuk membelajarkan siswa (mengarahkan interaksi siswa dengan sumber belajar lainnya) dalam rangka mencapai tujuan yang diharapkan.

Pembelajaran Sejarah Indonesia dirancang untuk mencapai tujuan menumbuhkan kesadaran sebagai bagian bangsa Indonesia yang memiliki rasa bangga dan cinta tanah air. Mempelajari sejarah bukan hanya sekedar mempelajari angka tahun dan nama tokoh namun lebih dari itu mempelajari sejarah berarti pula mempelajari nilai dari sebuah peristiwa sejarah. Fungsi sejarah pada hakekatnya adalah untuk meningkatkan pengertian atau pemahaman yang mendalam dan lebih baik tentang masa lampau dan juga masa sekarang dalam inter-relasinya dengan masa datang. Sejarah merupakan dialog antara peristiwa masa lampau dan perkembangan ke masa depan (Kochar, 2008). Sedangkan kegunaan atau manfaat sejarah ada empat; pertama bersifat edukatif (pelajaran sejarah membawa kebijaksanaan dan kearifan, kedua bersifat inspiratif (memberi ilham), ketiga bersifat instruktif (membantu kegiatan menyampaikan pengetahuan atau keterampilan), dan keempat bersifat rekreatif (memberikan kesenangan estetis berupa kisah-kisah nyata yang dialami manusia (Febrianti, 2015). 
Candi Muara Jambi merupakan salah satu kajian dalam mata kuliah Sejarah Indonesia hingga abad 15 Masehi. Candi Muara Jambi merupakan bagian dari sejarah lokal di Provinsi Jambi. Menurut (Priyadi, 2012) istilah lokal mempunyai suatu tempat atau ruang, sehingga sejarah lokal menyangkut lokalitas tertentu yang disepakati oleh para penulis sejarah, atau sejarawan dengan alasan-alasan ilmiah. Menurut Batasan lokal ini menyangkut aspek geografis yang merupakan tempat tingggal suku bangsa, suatu kota atau desa. Sebaliknya Wasino (2009) mengatakan bahwa sejarah lokal adalah sejarah yang posisi kewilayahannya di bawah sejarah nasional. Sejarah lokal baru muncul setelah adanya kesadaran nasional. Namun demikian bukan berarti semua sejarah lokal harus memiliki keterkaitan dengan sejarah nasional. Sejarah lokal bisa mencakup peristiwa-peristiwa yang memiliki keterkaitan dengan sejarah nasional dan peristiwa-peristiwa khas lokal yang tidak berhubungan dengan peristiwa yang lebih luas seperti nasional, regional, atau internasional. Dengan demikian secara sederhana dapat dikatakan bahwa sejarah lokal adalah bidang kajian masa lalu dari suatu kelompok atau masyarakat yang mendiami unit wilayah yang terbatas. Ruang sejarah lokal merupakan lingkup geografis yang dapat dibatasi oleh sejarawan dengan alasan yang dapat diterima oleh semua orang.

Mempelajari sejarah lokal dapat memberi pemahaman tentang akar sejarahnya dan dapat memahami perkembangan masyarakat pada tingkat lokal. Candi Muara Jambi yang ada di Provinsi Jambi memiliki peran penting dalam perkembangan masyarakat Jambi. Situs ini merupakan peninggalan masa Hindu Buddha. Situs candi Muara Jambi sebuah kompleks percandian terluas di Asia Tenggara, dengan luas 3.981 hektar. Kompleks percandian ini diperkirakan merupakan suatu peninggalan Kerajaan Sriwijaya, Kerajaan Melayu. Kompleks percandian terletak di Kecamatan Muara Sebo, Kabupaten Muara Jambi, Provinsi Jambi. Kompleks percandian Muara Jambi terletak pada tanggul alam kuno Sungai Batanghari. Situs ini sebagian besar masih berupa gundukan tanah (menapo) yang belum dikupas (diokupasi). Di dalam kompleks tersebut tidak hanya terdapat candi tetapi juga ditemukan parit atau kanal kuno buatan manusia, kolam tempat penampungan air serta gundukan tanah yang di dalamnya terdapat struktur bata kuno. Dalam kompleks tersebut minimal terdapat 85 buah menapo yang saat ini masih berada di atas tanah yang dimiliki oleh penduduk setempat.

Namun sayang masih banyak mahasiswa yang belum mengetahui tentang sejarah Candi Muara Jambi dan apa fungsi serta dampaknya bagi perkembangan masyarakat Jambi secara umum. Untuk itu diperlukan 
Nur Agustiningsih, Satriyo Pamungkas

Analisis Kebutuhan Pengembangan Media Pembelajaran Video Candi Muara Jambi Berbasis Sejarah Lokal Pada Mata Kuliah Sejarah Indonesia

informasi yang lebih dalam tentang keberadaan Candi Muara Jambi sehingga menumbuhkan kesadaran sejarah dan memunculkan kreativitas siswa dengan cara modern sehingga mahasiswa mampu menggali kearifan lokal masyarakat Jambi. Untuk itu diperlukan pembelajaran inovatif untuk menyampaikan informasi atau materi pembelajaran tentang Sejarah Lokal Jambi.

Menurut UU No. 20 Tahun 2003 tentang Sisdiknas Pasal 1 Ayat 20, Pembelajaran adalah proses interaksi peserta didik dengan pendidik dan sumber belajar pada suatu lingkungan belajar. Oleh karena itu, ada lima jenis interaksi yang dapat berlangsung dalam proses belajar dan pembelajaran, yaitu: 1) interaksi antara pendidik dan peserta didik, 2) interaksi antara sesama peserta didik atau antar sejawat, 3) interaksi peserta didik dengan narasumber, 4) interaksi peserta didik bersama pendidik dengan sumber belajar yang sengaja dikembangkan, dan 5) interaksi peserta didik bersama pendidik dengan lingkungan sosial dan alam (Rusman, 2013).

Perkembangan teknologi yang begitu cepat dan pengaruhnya begitu besar terhadap peserta didik menuntut adanya inovasi dan kreativitas dalam pembelajaran sejarah sehingga sejarah dapat disampaikan dengan menarik. Pada umumnya pembelajaran memerlukan media agar hal-hal yang bersifat verbal dapat ditampilkan secara visual agar dapat dipahami degan baik oleh peserta didik. Sanjaya dalam (Hamid, 2014) menjelaskan media pembelajaran adalah segala sesuatu seperti alat, lingkungan, dan segala bentuk kegiatan yang dikondisikan untuk menambah pengetahuan, mengubah sikap, atau menanamkan keterampilan pada setiap orang yang memanfaatkannya. Media dapat juga didefenisikan sebagai perantara atau pengantar terjadinya komunikasi dari pengirim menuju penerima. Media pembelajaran merupakan sarana pelantara dalam proses pembelajaran (Daryanto, 2011).

Menurut Daryanto (2011) penggunaan media dalam proses pembelajaran memiliki manfaat seperti memperjelas pesan agar tidak terlalu verbalis, mengatasi keterbatasan ruang, waktu, tenaga, dan daya indra, menimbulkan gairah, memungkinkan peserta didik belajar secara mandiri, memberi rangsangan, dapat menyalurkan pesan, serta dapat mengomunikasikan lima komponen pembelajaran yaitu guru, bahan pembelajaran, media pembelajaran, peserta didik, dan tujuan pembelajaran. Menurut Rustaman dalam (Susanto, 2014) media digunakan sebagai perantara untuk menyampaikan pesan dengan menggunakan alat penampil dalam kegiatan pembelajaran untuk meningkatkan efektivitas dan efisiensi pencapaian tujuan pembelajaran sejarah. Seringkali pendidik bingung menentukan media pembelajaran sejarah yang sesuai. Untuk mengatasi masalah tersebut pendidik dapat mengembangkan media pembelajaran 
sejarah sendiri sesuai dengan kebutuhan kurikulum maupun kebutuhan peserta didik.

\section{Metode}

Penelitian ini merupakan penelitian awal yang termasuk di dalam tahap pra pengembangan dalam prosedur penelitian dan pengembangan ( $R \& D)$. Penelitian ini hanya terbatas pada analisis kebutuhan (need assesment) yang bersumber dari hasil observasi awal di lapangan dan juga kajian terhadap literatur-literatur yang relevan. Metode penelitian yang digunakan adalah metode kualitatif. Metode penelitian kualitatif adalah metode penelitian yang digunakan untuk meneliti pada kondisi objek yang alamiah (sebagai lawannya adalah eksperimen) di mana peneliti adalah sebagai instrumen kunci. Teknik pengumpulan data dilakukan secara triangulasi yaitu teknik pengumpulan data yang bersifat penggabungan dari berbagai teknik pengumpulan data dan sumber data yang telah ada, analisis data bersifat induktif, dan hasil penelitian kualitatif lebih menekankan makna dari pada generalisasi (Sugiyono, 2011).

Teknik pengumpulan data dalam penelitian ini yaitu wawancara, observasi dan analisis dokumen. Wawancara dilakukan sesuai dengan prosedur yang telah dirancang sebelumnya sehingga diperoleh informasi penting yang sesuai dengan rencana penelitian. Persiapan wawancara dilakukan dengan berpedoman kepada kerangka tertulis berupa daftar pertanyaan. Dengan adanya pedoman wawancara dapat mencegah peneliti gagal memperoleh data penting yang dibutuhkan. Dalam penelitian ini wawancara dilakukan dengan dosen pengampu mata kuliah sejarah Indonesia hingga abad 15 masehi. Di samping itu wawancara juga dilakukan dengan mahasiswa yang dipilih berdasarkan kriteria, yakni mahasiswa yang memiliki kemampuan akademik tinggi, sedang dan rendah. Observasi dilakukan pada saat dosen mengajar di kelas. Analisis dokumen dilakukan melalui analisis dokumen Rencana Program Semester (RPS).

Teknik pemilihan informan yakni purposive sampling, karena penelitian senantiasa cenderung memilih informan yang dianggap tahu dan dapat dipercaya sepenuhnya sebagai sumber data serta mengetahui permasalahan yang diteliti secara mendalam. Data yang terkumpul diperiksa keabsahannya dengan menggunakan teknik triangulasi. Dalam pengumpulan data, triangulasi diartikan sebagai teknik pengumpulan data dan sumber data yang telah ada. Triangulasi metode berarti peneliti menggunakan teknik pengumpulan data yang berbeda-beda untuk mendapatkan data dari sumber yang sama. Peneliti menggunakan observasi, wawancara mendalam, dan dokumentasi untuk sumber data yang sama secara serempak. Triangulasi 
Nur Agustiningsih, Satriyo Pamungkas

Analisis Kebutuhan Pengembangan Media Pembelajaran Video Candi Muara Jambi Berbasis Sejarah Lokal Pada Mata Kuliah Sejarah Indonesia

sumber berarti peneliti menggunakan teknik pengumpulan data yang sama dari sumber yang berbeda-beda (Sugiyono, 2011).

Triangulasi data dalam penelitian ini meliputi: (1) triangulasi metode yaitu mengecek data dari sumber yang sama dengan teknik yang berbeda. Dalam hal ini menganalisis data yang diperoleh dari dosen dan mahasiswa melalui wawancara, observasi, dan dokumentasi dan (2) triangulasi sumber yaitu dilakukan dengan cara mendapatkan data yang sejenis dari beberapa sumber. Sumber data tersebut adalah dosen dan mahasiswa, kegiatan pembelajaran, dan dokumen.

Dalam penelitian ini analisis data dilakukan dengan model interaktif. Analisis data ditunjukkan pada gambar berikut:

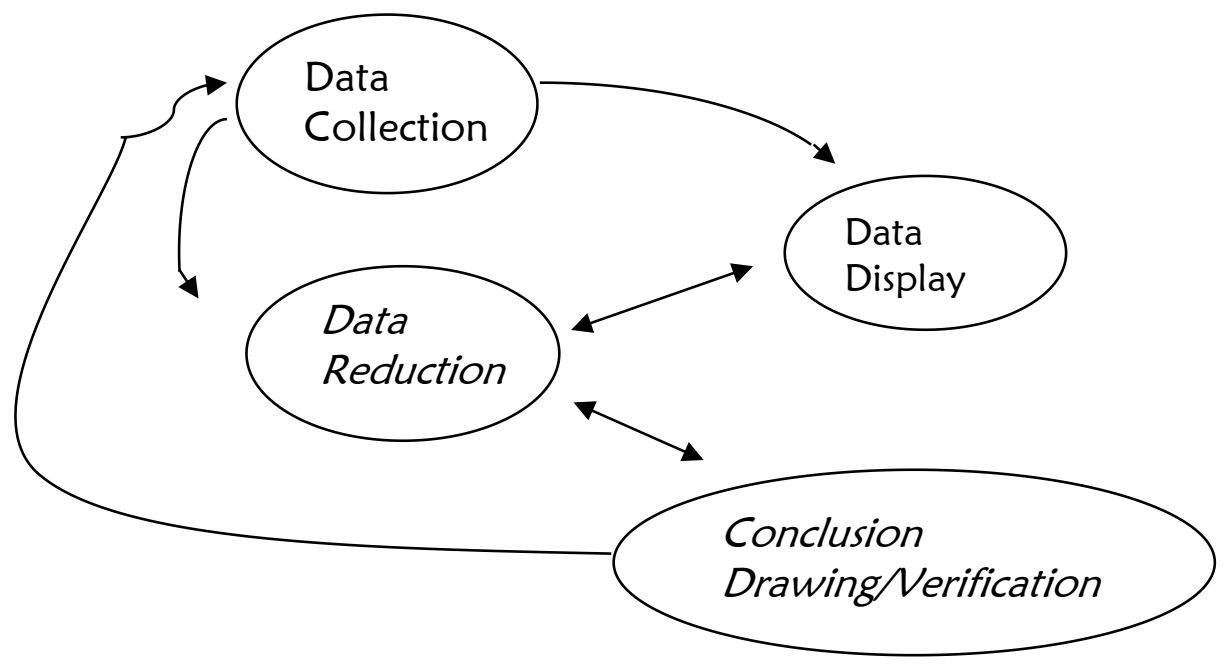

Bagan 1. Komponen Analisis Data (Interactive Model) Sumber : Sugiyono (2011: 247)

1. Data Reduction ( Reduksi data)

Mereduksi data berarti memilih hal-hal yang pokok, memfokuskan pada hal-hal yang penting, dicari tema dan polanya dan membuang yang tidak perlu. Dengan demikian data yang telah direduksi akan memberikan gambaran yang lebih jelas, dan mempermudah peneliti untuk melakukan pengumpulan data selanjutnya, dan mencarinya lagi bila diperlukan.

2. Data Display ( Penyajian Data)

Penyajian data bisa dilakukan dalam bentuk uraian singkat, bagan, hubungan antar kategori, flowchart, dan sejenisnya. Yang paling sering digunakan dalam penyajian data adalah dengan teks yang bersifat naratif. 
Dengan mendisplaykan data, maka akan memudahkan untuk memahami apa yang terjadi, merencanakan kerja selanjutnya berdasarkan apa yang telah dipahami tersebut. Dalam melakukan display data, selain dengan teks yang naratif juga dapat berupa grafik, matrik, network (jejaring kerja) dan chart.

\section{Conclusion Drawing/Verification}

Kesimpulan awal yang dikemukakan masih bersifat sementara, dan akan berubah bila ditemukan bukti-bukti yang kuat yang mendukung pada tahap pengumpulan data berikutnya, tetapi apabila kesimpulan yang dikemukakan pada tahap awal didukung oleh bukti-bukti yang valid dan konsisten saat peneliti kembali ke lapangan untuk mengumpulkan data, maka kesimpulan yang dikemukakan merupakan kesimpulan yang kredibel. Dengan demikian kesimpulan dapat menjawab rumusan masalah yang dirumuskan sejak awal, tetapi mungkin juga tidak. Seperti yang telah dikemukakan Sugiyono (2011) bahwa masalah dan rumusan masalah dalam penelitian kualitatif masih bersifat sementara dan akan berkembang setelah peneliti berada di lapangan.

\section{Hasil dan Pembahasan}

Pada tahap ini peneliti menggunakan teknik observasi dan wawancara yang dilakukan terhadap mahasiswa dan dosen pengampu dan analisis terhadap dokumen RPS mata kuliah Sejarah Indonesia Hingga Abad 15 M. Proses kegiatan ini dilakukan guna mendapatkan informasi mengenai proses pembelajaran, karakteristik mahasiswa, tujuan pembelajaran, media pembelajaran yang tersedia, serta informasi lainnya yang mendukung dalam pembuatan media pembelajaran.

Kurikulum yang digunakan di Universitas Batanghari khususnya pada prodi Pendidikan Sejarah yaitu Kurikulum berbasis KKNI. Pada RPS Mata Kuliah Sejarah Indonesia Hingga Abad $15 \mathrm{M}$, fokus kajiannya mengenai perkembangan bangsa Indonesia sejak adanya interaksi dengan dunia luar hingga runtuhnya kerajaan-kerajaan Hindu-Buddha sekitar abad ke-15 M. Sementara pada proses pembelajarannya menggunakan pendekatan multidimensi dengan model perkuliahan yang berpusat kepada mahasiswa atau studenst centre learning. Menurut Harsono (2008) student centre learning merupakan strategi pembelajaran yang menempatkan mahasiswa sebagai subyek/peserta didik yang aktif dan mandiri, dengan kondisi psikologik sebagai adult learner, bertanggung jawab sepenuhnya atas pembelajarannya, serta mampu belajar beyond the classroom. Dengan prinsip 
Nur Agustiningsih, Satriyo Pamungkas

Analisis Kebutuhan Pengembangan Media Pembelajaran Video Candi Muara Jambi Berbasis Sejarah Lokal Pada Mata Kuliah Sejarah Indonesia

ini maka para mahasiswa diharapkan memiliki dan menghayati jiwa life-long learner serta menguasai hard skills dan soft skills yang saling mendukung. Di sisi lain, para dosen beralih fungsi menjadi fasilitator, termasuk sebagai mitra pembelajaran, tidak lagi sebagai sumber pengetahuan utama

Selain itu, tujuan dari mata kuliah tersebut adalah memberikan pemahaman kepada mahasiswa mengenai sejarah awal bangsa Indonesia dan memperluas wawasan mahasiswa dalam melihat proses pembentukan bangsa Indonesia seperti adanya sekarang ini yang diwarnai oleh pola masyarakat yang multi etnis, multi budaya dan multi agama dan kepercayaan. Melalui pemahaman tersebut diharapkan akan menumbuhkan penghormatan dan penghargaan akan keanekaragaman tersebut dalam perspektif sejarah kebangsaan Indonesia. Hal ini ada hubungannya antara bukti masa HinduBuddha, salah satunya yang berada di Jambi yaitu Candi Muara Jambi sehingga membentuk masyarakat Jambi yang beranekaragam. Candi Muara Jambi ini merupakan salah satu sejarah lokal yang ada di provinsi Jambi.

Dari hasil wawancara dengan dosen maupun dengan mahasiswa diperoleh data bahwa metode pembelajaran yang sering digunakan oleh dosen adalah metode ceramah dan diskusi. Sementara itu dalam proses pembelajaran dalam penyampaian materi dosen lebih sering menggunakan power point sebagai media untuk menampilkan materi dalam bentuk gambar dan teks saja dan media yang digunakan masih kurang bervariasi. Hal ini menjadi salah satu dasar perlu dilakukan pengembangan media pembelajaran agar mahasiswa bisa melihat secara nyata kondisi Candi Muara Jambi dan temuan-temuan lainnya yang ada di situs percandian sebagai bukti dari adanya interaksi bangsa asing di daerah Jambi.

Dosen juga mengalami kendala dalam memperoleh referensi dan sumber belajar yang berkaitan dengan sejarah Candi Muara Jambi. Menurut Duffy dan Jonassen dalam Abdullah (2012), pemanfaatan berbagai sumber belajar merupakan upaya pemecahan masalah belajar. Sedangkan peran teknologi pendidikan sebagai pemecahan masalah belajar dapat terjadi dalam bentuk sumber belajar yang dirancang, dipilih dan/atau dimanfaatkan untuk keperluan belajar. Sumber-sumber belajar tersebut diidentifikasikan sebagai pesan, orang, bahan, alat, teknik, dan latar. Dalam mempersiapkan media pembelajaran dosen biasanya mendownload gambar-gambar dari internet. Namun menurut dosen pengampu media gambar yang digunakan masih belum cukup memberikan gambaran yang menyeluruh tentang kompleks Candi Muara Jambi. Media gambar yang sifatnya statis dan hanya menekankan pada aspek visual saja masih kurang menarik minat mahasiswa dalam pembelajaran. 
Berdasarkan hasil wawancara dengan mahasiswa, sebagian besar menyatakan mereka lebih tertarik dengan penggunaan media berupa video karena dapat menampilkan gambar, teks dan suara. Seperti pada hasil penelitian Purwanti (2015) menyebutkan bahwa penggunaan media video pembelajaran mengefektifkan pembelajaran dan presepsi terhadap pembelajaran menjadi lebih positif dengan daya tarik penggunaan media video pembelajaran memotivasi peserta didik dalam belajar. Selanjutnya penelitian dilakukan oleh Febrianti (2015) yang mengembangkan media video pembelajaran, yang mana pada hasil penelitiannya menyimpulkan bahwa media video pembelajaran dapat meningkatkan kesadaran sejarah.

Tersedianya sarana dan prasarana di setiap kelas memungkinkan proses pembelajaran menggunakan media video baik itu infocus, proyektor, dan sound system. Khususnya sound system merupakan inventaris prodi pendidikan sejarah yang dapat digunakan oleh dosen untuk kepentingan pembelajaran. Adanya sarana video pembelajaran Sejarah Candi Muaro Jambi dapat diputar di kelas. Selain itu mahasiswa memiliki produk-produk teknologi seperti Handphone ( $\mathrm{Hp}$ ) berjenis android yang memiliki aplikasi pemutar video. Mahasiswa bisa mengcopy media video tersebut untuk memutar ulang di Hp dan mempelajari ulang secara individu.

Mahasiswa saat ini merupakan mahasiswa yang tumbuh dalam pesatnya perkembangan teknologi, sehingga interaksi dengan internet maupun media sosial sangat intensif mereka lakukan. Selain itu mereka memiliki kemampuan yang cepat dalam beradaptasi dengan penggunaan produk teknologi. Kakrakteristik mahasiswa yang demikin mengharuskan dosen melakukan inovasi-inovasi dalam pembelajaran, salah satunya adalah mengembangkan media pembelajaran yang mudah diakses oleh mahasiswa melalui perangkatperangkat teknologi yang mereka miliki.

Analisis materi yaitu dengan cara mengidentifikasi kemampuan akhir yang diharapkan dan tertera pada silabus yaitu mampu menganalisis pengaruh bangsa luar di Jambi dan menyebutkan peninggalan-peninggalan masa Hindu-Buddha khususnya di Provinsi Jambi. Dari identifikasi tersebut maka didapatkan materi yang akan dimasukkan dalam media pembelajaran dan disusun secara sistematis untuk disajikan pada media video pembelajaran sejarah Candi Muara Jambi. 
Nur Agustiningsih, Satriyo Pamungkas

Analisis Kebutuhan Pengembangan Media Pembelajaran Video Candi Muara Jambi Berbasis Sejarah Lokal Pada Mata Kuliah Sejarah Indonesia

\section{Simpulan}

Berdasarkan hasil penelitian yang diperoleh dapat diambil kesimpulan sebagai berikut:

1. Dosen mata kuliah sejarah Indonesia Hingga Abad $15 \mathrm{M}$ telah menggunakan media pembelajaran namun kurang bervariasi, media yang sering digunakan adalah powerpoint yang didalamnya terdapat teks dan gambar.

2. Kendala yang dihadapi dosen dalam pembelajaran adalah kesulitan dalam memperoleh referensi dan sumber belajar yang berkaitan dengan sejarah candi Muara Jambi.

3. Mahasisw lebih tertarik menggunakan media berupa video dalam pembelajaran karena dapat menampilkan gambar, teks dan suara sehingga pembelajaran menjadi lebih menarik.

\section{Daftar Rujukan}

Abdullah, R. (2012). Pembelajaran berbasis pemanfaatan sumber belajar. $X I /(2), 216-231$.

Daryanto. (2011). Media Pembelajaran. Bandung: Yrama Widya.

Febrianti, A. N. (2015). Pengembangan Media Pembelajaran Sejarah Berbasis Audio Visual Situs Purbakala Pugung Raharjo Untuk Meningkatkan Kesadaran Sejarah Siswa Kelas X SMA Negeri 1 Kota Gajah,. IImiah Dikdaya, 29-45.

Hamid, A. R. (2014). Pembelajaran Sejarah. Yogyakarta: Ombak.

Harsono. (2008). Student-Centered Learning di Perguruan Tinggi. Pendidikan Kedokteran Dan Profesi Kesehatan Indonesia, 3 (1), 1-8.

Kochar, S. K. (2008). Pembelajaran Sejarah, Penerjemah Purwanta dan Yovita Hardiwati. Jakarta: PT Grasindo.

Priyadi, S. (2012). Sejarah Lokal Konsep, Metode, dan Tantangannya. Yogyakarta: Ombak.

Purwanti, B. (2015). Pengembangan Media Video Pembelajaran Matematika dengan Model Assure. Kebijakan Dan Pengembangan Pendidikan, 3, 4247.

Rusman. (2013). Belajar dan Pembelajaran Berbasis Komputer. Bandung: Alfabeta.

Sanjaya, W. (2008). Perencanaan dan desain sistem pembelajaran. Kencana.

Sugiyono. (2011). Metode Penelitian Pendidikan. Bandung: Alfabeta.

Susanto, H. (2014). Seputar Pembelajaran Sejarah. Yogyakarta: Aswaja Pressindo.

Trianto. (2007). Model-model pembelajaran inovatif berorientasi Konstruktivistik. Jakarta: Prestasi Pustaka.

Wasino. (2009). Pokok-Pokok Pikiran Untuk Penulisan Sejarah Lokal. Sarasehan Koordinasi dan Curah Pendapat Penguatan Sejarah Lokal 
DIAKRONIKA

18 (1) 2018

ISSN: 1411-1764 (Print) | 2620-9446 (Online)

untuk Meningkatkan Wawasan Kebangsaan Deputi Menko Kesra Bidang Koordinasi Kebudayaan Paariwisata Pemuda dan Olah Raga. Makalah. 